\title{
Accessibility and Reliability of Information Sources in Dissemination of Soil Fertility Management in Eastern Kenya
}

\author{
Kimaru-Muchai ${ }^{*}$ S.W. Mucheru-Muna ${ }^{2}$ M. $\quad$ Mugwe $^{3}$ J.N. \\ 1.Department of Social and Development Studies, Mt. Kenyatta University P.O Box 342-01000, Thika \\ 2.Department of Environmental Science, Kenyatta University P.O Box 43844 Nairobi \\ 3.Department of Agricultural Resource Management, Kenyatta University P.O Box 43844 Nairobi
}

\begin{abstract}
Increased recognition of soil fertility depletion as the main factor limiting crop production in many small holder farms in sub-Saharan African has renewed interest in the dissemination of soil fertility management technologies. Despite soil technology development and research outputs, few of the recommendations from various soil fertility management research activities have been adopted by the small-scale farmers on a large-scale level. Only a small proportion of allocated research resources is invested in dissemination among research institutions. The objective of the study was to investigate communication channels used in dissemination of soil fertility management practices in Mbeere and Meru South Districts. Two hundred and forty randomly selected farmers were interviewed. Data collected was analyzed using SPSS. The study revealed that $32.5 \%$ of the farmers who used combined organic and inorganic fertilizers received information from government extension officers while $41.3 \%$ of the farmers who use animal manure utilized their own farming experience. In disseminating soil erosion control measures, $51.2 \%$ of the farmers indicated that, farmer to farmer extension was the most commonly used. Also, $33.8 \%$ mentioned demonstration as the main method used in training soil fertility management practices. In general, the most common source of information was other farmers while there was least participation of researchers and agro input dealers in dissemination of soil fertility technologies. Thus, the study recommended more participation of stakeholders other than government extension officers as well as use of combined extension methods with farmer involvement in dissemination of soil fertility management practices. Keywords: manure, extension agents, farmer to farmer extension method, demonstration
\end{abstract}

DOI: $10.7176 / \mathrm{DCS} / 10-11-03$

Publication date: November $30^{\text {th }} 2020$

\section{INTRODUCTION}

Soil fertility depletion in small holder farms is the fundamental biophysical root cause of declining per capital food production in Africa (Sanchez et al., 1996). Food deficits in many parts of sub-Saharan Africa can be offset through reversing the current trends of declining soil fertility and agricultural productivity (Onduru et al., 2002). Nevertheless, the useful replenishment technologies that have been generated have however not been adopted by the farmers as anticipated by the researchers (Kamau et al., 2002). For example, in central Kenya, increase in maize yield with application of tithonia, calliandra and leucaena biomass has been reported (Mugendi et al., 1999). while in another study combination of organic materials and inorganic fertilizers has been shown to result to higher maize yields as compared to the use of inorganic fertilizer alone (Mugwe at al .,2008). Adoption of these technologies on a wider scale is a concern of many practitioners in rural development (Ashby, 2003). The biggest challenge to the accessibility and utilization of the existing knowledge lies with the inadequacies in the communication methods and tools used in dissemination and up scaling of soil fertility management practices.

Communication is the process of sharing or conveying information by which ideas are transferred from a source to a receiver with the intent to change his or her knowledge, attitude and skill (Adebayo, 1995). Evidence abounds that farmers on many occasions use different information sources to meet their soil fertility needs. Ekoja (2003) explained that most commonly used sources of information in Nigeria include extension agents, neighbors, other farmers, opinion leaders and organized groups. On the other hand, Maddox et al. (2003) reported that in North Carolina (NC) sources of information included, other farmers, NC Department of Agriculture extension agents, NC Cooperatives extension gents, magazine articles, family, friends, and neighbors, organizational newsletters bulletins, fact sheets, on-farm visits and meetings. Rogers (1995) explained that most commonly used channels of communication include mass media (radio and television), print media (pamphlets, brochures, labels and magazines) and inter-personal media (seminars, demonstrations, field days exchange visits and agricultural shows). Different sources of information are important as they make the farmers aware of alternatives from where they can choose the most desirable soil fertility technology suited to their needs. The change agents, researchers, extension workers and policy makers need to identify those sources of information that farmers use most as this will help in appraising effective communication pathways in dissemination of soil fertility management practices.

An effective extension communication is a necessity for extension service to achieve its broad set goal of farmers acquiring knowledge, skill and attitude and in the overall, better their economic strength and hence their 
level of living (Okunade, 2007). Extension workers use variety of extension methods to disseminate information regarding soil fertility management practices. According to Farouque and Takeya (2009), the more ways a topic is presented and practical, the more quickly people will tend to grasp the subject matter. Rogers (1995), explained adoption of a new technology depends on several factors such as its relative advantages, compatibility with existing practices, complexity, trainability and observability. Adoption also depends on the selection of appropriate extension methods by extension providers

Garforth (1993) classified extension teaching methods into three broad classes in terms of area of coverage as follows (1) Individual contact methods, 2) Group methods (3) Mass methods. Individual contact methods are superior for conviction and action because of face to face relation ship of a teacher and a learner (Okunade, 2007). They include farm and home visits, office calls and telephone calls. Group methods include demonstration, exchange visits, farmer field schools (FFS), field days, workshops and exhibitions. Mass media methods are methods to reach many people at the same time for example electronic media such as radio, television, internet and print media like brochure, newsletters, manuals, books and magazines. According to Sim and Hilmi (1987), field days, tours and demonstration are some of the methods that have been used by research and extension agents. However, limited financial resources may force extension agents to choose among teaching methods and events. In such cases understanding the target audience, including the methods by which they prefer to receive information, allows agents to select the most effective teaching methods and events accordingly and to transfer information efficiently (Richardson and Mustian, 1994).

This study therefore endeavored to asses the availability and reliability of information sources and find out the communication methodologies and approaches that are preferred on promotion and scaling up knowledge on soil fertility management technologies hence increase agricultural productivity and poverty reduction.

The main objective of this study was to assess the various sources of information on soil fertility and the extension methods used in dissemination of soil fertility management practices among the small holder farmers. The specific objectives are to;

i. To identify sources of information utilized by farmers in order to improve soil fertility on their farms.

ii. To assess the availability and accessibility of information sources as perceived by the farmers.

iii. To identify the extension methods used in teaching farmers soil fertility management practices.

iv. To analyse the social economic factors that affect farmers' preferences of extension approaches used in dissemination of soil fertility management practices.

\section{METHODOLOGY}

\section{Study Area}

The research was carried out in Mwimbi division in Maara district (formerly in Meru South) and in Gachoka division in Mbeere South district in the Central highlands of Kenya. The choice of the study area was based on the fact that several research projects on soil fertility management practices have been conducted in the region. Mwimbi division lies in the Upper Midland Agro-ecological Zone (UM2-UM3) (Jaetzold et al., 2006) on the eastern slopes of Mount Kenya at an altitude of $1500 \mathrm{~m}$ a.s.l. with annual mean temperature of $20^{\circ} \mathrm{C}$ and total annual rainfall ranging from 1200 to $1400 \mathrm{~mm}$. The rainfall is bimodal with long rains (LR) from March to June and short rains (SR) from October to December. The soils are mainly humic Nitisols (Jaetzold et al., 2006) which are deep, well weathered with moderate to high inherent fertility but this has declined over time with poor management. It is highly populated with smallholdings ranging from 0.1 to 2 ha with an average of 1.2 ha per household. This has led to the exploitation of decreasingly productive lands and increasing soil erosion potential. Gachoka division lies at the transition between the marginal cotton (LM4) and the main cotton (LM4) agroecological Zones (Jaetzold et al., 2006) at an altitude of approximately $800 \mathrm{~m}$ a.s.l. with an annual mean temperature ranging from 21.7 to $22.5^{\circ} \mathrm{C}$ and average annual rainfall ranging from 700 to $900 \mathrm{~mm}$. The rainfall is bimodal with long rains (LR) from mid March to June and short rains (SR) from late October to December hence two cropping seasons per year. The soils are predominantly Ferralsols and Acrisols (Jaetzold et al., 2006).

\section{Sampling and sample size}

Ganga location in Mwimbi division and Mbita location were purposively selected for the study. The researcher obtained all the household names from the sub chiefs of the respective villages. Systematic random sampling technique was used to select 120 farmers from each location. In all, two hundred and forty (240) respondents were selected for the research. The selected farmers were interviewed using structured and unstructured questionnaires in May 2010. Pre- testing of the questionnaires was carried out to ensure accurate and precise collection of data.

\section{Data Analysis procedure}

Data collected was first summarised and a data base template containing the collected information was made using statistical package for social sciences (SPSS) computer software. Descriptive statistics such as frequency 
counts, percentages mean, and standard deviation were used to display the data. Inferential statistics such as Kendal's tau correlation and multiple regression analysis were used to test the hypothesis of the study. Kendal's tau correlation (r) analysis was used to determine the relationship between the dependent variable (Approach preference) and independent variables.

Multiple regression analysis was also employed to determine the magnitude of change in the farmers level of preference of communication approaches used in dissemination of soil fertility management practices. Approach preference (dependent variable) was regressed to social economic attributes (independent variables). The model used was as follows;

$\mathrm{Y}=\mathrm{a}+\mathrm{b}_{1} \mathrm{x}_{1}+\mathrm{b}_{2} \mathrm{X}_{2}+\ldots \ldots+\mathrm{b}_{\mathrm{p}} \mathrm{x}_{15}+\mathrm{e} \ldots 1$

Where

$\mathrm{Y}=$ preference level of approaches used to communicate soil fertility management practices

$\mathrm{X}_{1}-\mathrm{X}_{15}=$ independent variable

$\mathrm{a}=\mathrm{y}$ intercept

$b=$ regression coefficients

$\mathrm{e}=$ error term

\section{RESULTS}

Table 1 reveals the social-economic characteristics of the farmers interviewed in the study area.

Table 1: Distribution of respondents according to social-economic characteristics

\begin{tabular}{|c|c|c|}
\hline Social -economic factors & No. of Respondents & Percent (\%) \\
\hline \multicolumn{3}{|l|}{ Age (years) } \\
\hline $15-30$ & 27 & 11.3 \\
\hline $31-45$ & 95 & 39.6 \\
\hline $46-60$ & 85 & 35.4 \\
\hline$>61$ & 33 & 13.8 \\
\hline \multicolumn{3}{|l|}{ Gender } \\
\hline Male & 173 & 72.1 \\
\hline Female & 67 & 27.9 \\
\hline \multicolumn{3}{|l|}{ Level of Education } \\
\hline No Education & 13 & 5.4 \\
\hline Primary Education & 143 & 59.6 \\
\hline Secondary Education & 62 & 25.8 \\
\hline Tertiary Education & 22 & 9.2 \\
\hline \multicolumn{3}{|c|}{ Years of farming Experience } \\
\hline Less than 10 years & 46 & 19.2 \\
\hline $11-20 y r s$ & 81 & 33.8 \\
\hline Above 20 years & 113 & 47.1 \\
\hline \multicolumn{3}{|c|}{ Number of non formal trainings } \\
\hline None & 131 & 54.6 \\
\hline $1-5$ times & 83 & 34.6 \\
\hline 5-10 times & 17 & 7.1 \\
\hline More than 10 times & 9 & 3.8 \\
\hline \multicolumn{3}{|l|}{ Farm size (acres) } \\
\hline$<1$ & 62 & 25.8 \\
\hline $1.1-3$ & 117 & 48.8 \\
\hline $3.1-5$ & 42 & 17.5 \\
\hline$>5.1$ & 19 & 7.9 \\
\hline \multicolumn{3}{|l|}{ Wealth Status } \\
\hline Rich & 32 & 13.3 \\
\hline Middle & 195 & 81.3 \\
\hline Poor & 13 & 5.4 \\
\hline \multicolumn{3}{|c|}{ Membership in Farmers groups } \\
\hline 0 & 84 & 35.0 \\
\hline $1-2$ & 136 & 56.6 \\
\hline $3-4$ & 18 & 7.6 \\
\hline$>5$ & 2 & 0.8 \\
\hline \multicolumn{3}{|l|}{ Reason for farming } \\
\hline For food & 47 & 19.6 \\
\hline For income & 5 & 2.1 \\
\hline
\end{tabular}




\begin{tabular}{lcc}
\hline Social -economic factors & No. of Respondents & Percent (\%) \\
\hline For food and income & 188 & 78.3 \\
Money earned from farming in (K sh) & 13 & 5.4 \\
$0-5,000$ & 33 & 13.8 \\
$5,000-10,000$ & 47 & 19.7 \\
$10,000-15,000$ & 146 & 61.1 \\
\hline 15000 and above & & \\
\hline \multicolumn{2}{c}{ Majority of farmers interviewed, 39.6\% were between 31-45 years and only $13.8 \%$ were above 60 years }
\end{tabular}
while most households in the study were male headed, $173(72 \%)$. About $143(59.6 \%)$ of the respondents had attained primary education while $62(25.8 \%)$ and $22(9.2 \%)$ had attained secondary and tertiary education respectively. Majority of the farmers (47.1\%) had more than 20 years experience in farming while131 $(55 \%)$ had not attended any non formal training. Most of land parcels belonging to individual household varied from 0.25 to 15 acres in the surveyed area. Overall the average size of farm was 2.6 acres. Majority of the respondents $195(81.3 \%)$ belong to the middle class in terms of wealth status. Only $13(5.4 \%)$ of the respondents were judged as poor while $32(13.3 \%)$ were judged as rich. About $65 \%$ of the farmers are members of at least one farmers group or association. Results of the study revealed that $188(78 \%)$ of the respondents rely on farming for both food and income. However, 146(61\%) of the respondents realized an estimated income of above Ksh 15,000 per year, while $47(19 \%)$ of the respondents realized an estimated income between Ksh 10,000-15,000 as their average income per year.

\section{Sources of information}

According to the results, approximately $20.8 \%$ of the farmers received information on animal manure from government extension officers while $41.3 \%$ utilized their own farming experience. Based on the findings, $8.3 \%$ of the farmers who use green manure obtained information from government extension officers. About $36.7 \%$ of the farmers who practiced application of inorganic fertilizers obtained information from other farmers while $27.1 \%$ received information from government extension officers. As described in Table 2, majority (33.8\%) of the farmers who practice erosion control measures obtained information from other farmers. The results reveal that overall farmers utilized their own farming experience $(22.98 \%)$, obtained information from other farmers $(18.6 \%)$ and $16.7 \%$ obtained information on SFM practices from government extension officers.

Table 2: Sources of information for the different SFM practices used by farmers

\begin{tabular}{|c|c|c|c|c|c|c|c|c|c|c|c|c|}
\hline $\begin{array}{c}\text { Isfm } \\
\text { technology }\end{array}$ & \begin{tabular}{|c|} 
Does \\
Not \\
Practice \\
\end{tabular} & $\begin{array}{c}\text { Government } \\
\text { Extension } \\
\text { officer }\end{array}$ & $\begin{array}{c}\text { Ngo } \\
\text { extension officer }\end{array}$ & Researchers & $\begin{array}{c}\text { Agro } \\
\text { Input } \\
\text { Dealers }\end{array}$ & $\begin{array}{c}\text { Friends } \\
\text { And } \\
\text { Neighbours }\end{array}$ & $\begin{array}{c}\text { Radio/ } \\
\text { Tv }\end{array}$ & $\begin{array}{c}\text { News } \\
\text { Paper }\end{array}$ & $\begin{array}{c}\text { Exh } \\
\text { Ibitions }\end{array}$ & $\begin{array}{c}\text { Other } \\
\text { Farmers }\end{array}$ & $\begin{array}{c}\text { Your } \\
\text { Own } \\
\text { Experience }\end{array}$ & Total \\
\hline $\begin{array}{l}\text { Animal } \\
\text { manure } \\
\text { Green }\end{array}$ & $20(8.3)$ & $50(20.8)$ & $2(0.8)$ & $4(1.7)$ & $1(0.4)$ & $32(13.3)$ & $2(0.8)$ & $0(0)$ & $1(0.4)$ & $29(12.1)$ & $99(41.3)$ & $240(100)$ \\
\hline $\begin{array}{l}\text { manure) } \\
\text { Application }\end{array}$ & $187(77.9)$ & $20(8.3)$ & $0(0)$ & $13(5.4)$ & $1(0.4)$ & $1(0.4)$ & $1(0.4)$ & $2(0.8)$ & $0(0)$ & $3(1.3)$ & $12(5)$ & $240(100)$ \\
\hline $\begin{array}{l}\text { of inorganic } \\
\text { fertilizer } \\
\text { Combined } \\
\text { organic and }\end{array}$ & $11(4.6)$ & $65(27.1)$ & $3(1.3)$ & $6(2.5)$ & $23(9.6)$ & $11(4.6)$ & $3(1.3)$ & $1(0.4)$ & $3(1.3)$ & $88(36.7)$ & $26(10.8)$ & $240(100)$ \\
\hline $\begin{array}{l}\text { inorganic } \\
\text { fertlizers } \\
\text { Erosion }\end{array}$ & $26(10.8)$ & $78(32.5)$ & $17(7.1)$ & $10(4.2)$ & $5(2.1)$ & $18(7.5)$ & $2(0.8)$ & $1(0.4)$ & $4(1.7)$ & $50(20.8)$ & $29(12.1)$ & $240(100)$ \\
\hline $\begin{array}{l}\text { Control } \\
\text { measures }\end{array}$ & $23(9.6)$ & $43(17.9)$ & $10(4.2)$ & $2(0.8)$ & $2(0.8)$ & $26(10.8)$ & $3(1.3)$ & $0(0)$ & $0(0)$ & $81(33.8)$ & $50(20.8)$ & $240(100)$ \\
\hline $\begin{array}{l}\text { Compost } \\
\text { Use of }\end{array}$ & $167(69.6)$ & $9(3.8)$ & $3(1.3)$ & $2(0.8)$ & $1(0.4)$ & $8(3.3)$ & $0(0)$ & $0(0)$ & $0(0)$ & $20(8.3)$ & $30(12.5)$ & $240(100)$ \\
\hline $\begin{array}{l}\text { legumes } \\
\text { Cover }\end{array}$ & $88(36.7)$ & $22(9.2)$ & $1(0.4)$ & $5(2.1)$ & $7(2.9)$ & $10(4.2)$ & $0(0)$ & $0(0)$ & $0(0)$ & $30(12.5)$ & $77(32.1)$ & $240(100)$ \\
\hline $\begin{array}{l}\text { crops } \\
\text { Crop }\end{array}$ & $25(10.4)$ & $13(5.4)$ & $7(2.9)$ & $6(2.5)$ & $6(2.5)$ & $34(14.2)$ & $3(1.3)$ & $0(0)$ & $0(0)$ & $51(21.3)$ & $95(39.6)$ & $240(100)$ \\
\hline rotation & $19(7.9)$ & $61(25.4)$ & $6(2.5)$ & $4(1.7)$ & $1(0.4)$ & $21(8.8)$ & $2(0.8)$ & $0(0)$ & $0(0)$ & $49(20.4)$ & $77(32.1)$ & $240(100)$ \\
\hline Total & $566(26.2)$ & $361(16.7)$ & $49(2.3)$ & $52(2.4)$ & $47(2.2)$ & $161(7.5)$ & $16(0.7)$ & $4(0.2)$ & $8(0.4)$ & $401(18.6)$ & $495(22.9)$ & $2160(100)$ \\
\hline
\end{tabular}

N.B: Numbers in parentheses give the percentage of respondents

\section{Availability of sources of information}

Farmers were asked to score the availability of various sources of communication using the scores, 1 as the least available and 4 as the most available. The availability of information sources were ranked respectively (Table 3): other farmers $(\mathrm{M}=3.8)$, radio/TV $(\mathrm{M}=3.6)$ and government extension $(\mathrm{M}=2.2)$ were ranked as the first three sources of information respectively while print media (1.5) was ranked as the least available sources of information.

\section{Reliability of sources of information}

The data in Table 3 show the rank order of sources of information by reliability as perceived by the farmers. Other farmers, $(M=3.04)$, government extension officers $(M=2.61)$ and researchers $(1.94)$, were ranked as the first three reliable sources of information respectively while Agro-input-dealers were the least reliable source of information with a weighted mean of (1.47).

The results indicate that there was a non significant positive correlation between availability of information source and its reliability at $(\mathrm{r}=0.65, \mathrm{P} \leq 0.1)$. Therefore reliability of an information source depends largely on 
how farmers have been sensitized to a particular source.

Table 3: Availability Vs Reliability of Information Sources on Soil Fertility Management Practices

\begin{tabular}{|c|c|c|c|c|c|c|}
\hline Availability & Mean & Ranking & Reliability & & Mean & Ranking \\
\hline Sources of Information & & & Source of informa & tion & & \\
\hline Other farmers & 3.8 & 1 & Other farmers & & 3.09 & 1 \\
\hline Radio/TV & 3.6 & 2 & Radio/TV & & 1.84 & 4 \\
\hline $\begin{array}{l}\text { Government extension } \\
\text { worker }\end{array}$ & 2.2 & 3 & $\begin{array}{l}\text { Government } \\
\text { officers }\end{array}$ & Extension & 2.61 & 2 \\
\hline Exhibition/shows & 1.9 & 4 & Exhibition/shows & & 1.66 & 6 \\
\hline Researchers & 1.7 & 5 & Researchers & & 1.94 & 3 \\
\hline Agro-input-dealers & 1.7 & 6 & Agro-input-dealers & & 1.47 & 8 \\
\hline NGO extension worker & 1.5 & 7 & NGOs & & 1.77 & 5 \\
\hline Print media & 1.5 & 8 & print media & & 1.50 & 7 \\
\hline
\end{tabular}

Extension teaching methods used to teach on the various technologies practiced by farmers

The findings in Table 4 reveals that $97.9 \%$ of the farmers who use animal manure as a way of improving soil fertility were trained using demonstration while $51.2 \%$ and $42.9 \%$ of the farmers who practice soil erosion control measures and use inorganic fertilizers respectively were trained through the farmer to farmer extension method. None of the farmers who use animal manure were trained through field days, farmer field school (FFS) or through workshops. About $53.8 \%$ of the farmers who use green manure were trained through demonstration Table 4: Methods Used to teach Different Technologies Practiced by the Farmers.

\begin{tabular}{|c|c|c|c|c|c|c|c|c|}
\hline SFM practice & Demonstration & Exchange visit & Field days & FFS & $\begin{array}{l}\text { Workshop/ } \\
\text { Seminar }\end{array}$ & $\begin{array}{ll}\begin{array}{l}\text { Farmer } \\
\text { extension }\end{array} & \text { to farmer } \\
\end{array}$ & By listening & Totals \\
\hline Animal manure & $140(97.9)$ & $1(0.7)$ & $0(0)$ & $0(0)$ & $0(0)$ & $0(0)$ & $2(1.4)$ & $143(100)$ \\
\hline Green manure(specify) & $21(53.8)$ & $1(2.6)$ & $13(33.3)$ & $0(0)$ & $1(2.6)$ & $2(5.1)$ & $1(2.6)$ & $39(100)$ \\
\hline Application of inorganic fertilizer & $50(25.3)$ & $14(7.1)$ & $33(16.7)$ & $4(2)$ & $11(5.6)$ & $85(42.9)$ & $1(0.5)$ & $198(100)$ \\
\hline Combined organic fertilizers and inorganic fertilizers & $46(26.1)$ & $12(6.8)$ & $38(21.6)$ & $10(5.7)$ & $13(7.4)$ & $57(32.4)$ & $0(0)$ & $176(100)$ \\
\hline Erosion control measures & $56(33.3)$ & $10(6)$ & $8(4.8)$ & $2(1.2)$ & $5(3)$ & $86(51.2)$ & $1(0.6)$ & $168(100)$ \\
\hline Compost & $16(27.6)$ & $2(3.4)$ & $12(20.7)$ & $2(3.4)$ & $1(1.7)$ & $25(43.1)$ & $0(0)$ & $58(100)$ \\
\hline Use of legumes & $10(12.3)$ & $17(21)$ & $2(2.5)$ & $1(1.2)$ & $1(1.2)$ & $50(61.7)$ & $0(0)$ & $81(100)$ \\
\hline Cover crops & $17(13.1)$ & $4(3.1)$ & $18(13.8)$ & $11(8.5)$ & $8(6.2)$ & $70(53.8)$ & $2(1.5)$ & $130(100)$ \\
\hline Crop rotation & $31(20.5)$ & $16(10.6)$ & $23(15.2)$ & $3(2)$ & $9(6)$ & $67(44.4)$ & $2(1.3)$ & $151(100)$ \\
\hline Total & $387(33.8)$ & $77(6.7)$ & $147(12.8)$ & $33(2.9)$ & $49(4.3)$ & $442(38.6)$ & $9(0.8)$ & $1144(100)$ \\
\hline
\end{tabular}

N.B: Numbers in parentheses give the percentage of respondents

Table 5: Extension teaching methods preferred by farmers

\begin{tabular}{|c|c|c|c|c|c|c|c|c|c|c|}
\hline Communication Method & Green manure & Fertilizer & Compost & Animal manure & $\begin{array}{l}\text { Combined fertilizer } \\
\text { and manure }\end{array}$ & Soil Erosion & Legumes & crop rotation & Cover crops & Overall mean \\
\hline Field days & (4)1.99 & (3)2.50 & (5)2.13 & (4)2.10 & (4)2.15 & (4)2.30 & (4)2.25 & (4)2.40 & (4)2.32 & (4)2.24 \\
\hline FFS & (7) 1.67 & (5)2.18 & (1)3.49 & (7) 1.83 & (7) 1.93 & (7)2.13 & (7) 1.99 & (6)2.02 & (6)2.04 & (5)2.14 \\
\hline Demonstrations & (2)2.91 & (1)3.21 & (2)3.00 & (1)3.13 & (1)3.43 & (2)2.90 & (2)2.95 & (2) 2.92 & (2)2.88 & (1)3.04 \\
\hline Teaching Aids & (4) 1.99 & (5)2.18 & (4) 2.16 & (5)2.03 & (5)2.12 & (6)2.18 & (5)2.08 & (5)2.14 & (7) 2.03 & (6)2.10 \\
\hline Exchange visits & (6)1.86 & (7)2.06 & (7) 1.87 & (6)2.01 & (6)2.02 & (5)2.21 & (6)2.01 & (7)2.00 & (5)2.08 & (7)2.01 \\
\hline Workshops & (3)2.16 & (4)2.49 & (6)1.93 & (3)2.30 & (3)2.46 & (3)2.50 & (3)2.38 & (3)2.53 & (3)2.54 & (3)2.37 \\
\hline $\begin{array}{l}\text { Farmer to } \\
\text { farmer Extension }\end{array}$ & (1)3.00 & (2)2.90 & (3)2.98 & (2)2.90 & (2)3.20 & (1)3.10 & (1)2.96 & (1) 3.08 & (1)3.07 & (2) 3.02 \\
\hline
\end{tabular}

N.B: Numbers in parentheses give the rank of the extension method

\section{Preference of extension teaching methods as perceived by the farmers}

Table 5 shows that demonstration was the most preferred method in dissemination of SFM practices as it was ranked the first with a weighted mean score (WMS) of 3.04 and farmer to farmer extension was ranked second with a WMS of 3.02. Farmer field school (FFS) was ranked as the first (3.49) as an extension method in teaching on the use of compost manure. Exchange visit (2.01) was ranked the least overall as an extension method in teaching of SFM practices.

\section{Extension teaching approaches preferred by the farmers}

Farmers were asked to score the preference of approaches as follows, $1=$ Do not prefer, $2=$ mildly prefer and $3=$ strongly prefer. The data in Table 6 reveal that majority of the farmers $(67.1 \%)$ strongly preferred individual farmer interaction method. About $55 \%$ of the framers do not prefer mass media approach while $48.3 \%$ mildly 
preferred group approach .Individual farmer interaction was the highest ranked with weighted mean score of 2.48, followed closely by group approach (2.37) and the least ranked was mass media method (1.58).

Table 6: Extension teaching approaches preferred by the farmers

\begin{tabular}{lcccc}
\hline \multirow{2}{*}{\multicolumn{1}{c}{ Approach }} & \multicolumn{3}{c}{ Percent \% of respondents/Frequencies } \\
\cline { 2 - 5 } & do not prefer & mildly prefer & strongly prefer & Mean Scores \\
\hline Individual farmer interaction & $(8.8) 21$ & $(24.2) 58$ & $(67.1) 161$ & 2.58 \\
Group approach & $(7.5) 18$ & $(48.3) 116$ & $(44.2) 106$ & 2.37 \\
Mass media approach & $(55) 132$ & $(31.7) 76$ & $(13.3) 32$ & 1.58 \\
\hline
\end{tabular}

N.B: Numbers in parentheses give the percentage of respondents

Relationship between preference of extension teaching approaches and farmers social-economic characteristics

Table 7 shows there was positive and significant correlation $(\mathrm{P} \leq 0.01)$ between education level and individual farmer interaction. The positive correlation implies that the higher the education levels of the farmer the greater the preference of individual farmer interaction approach. Farm size was positively and significantly $(P \leq 0.05)$ correlated with the preference of mass media approach. Conversely, wealth status was negatively and significantly $(\mathrm{P} \leq 0.01)$ correlated with the preference of mass media. This implies that the richer the farmer the lesser the preference for mass media approach in teaching on the use of SFM practices. Similarly, there was negative but non significant relationship between estimated income from the farm and preference for mass media. On the other hand, there was positive and significant $(\mathrm{P}<0.05)$ correlation between gender and preference for group approach. This implies that female farmers preferred group approach more than the male farmers.

Table 7: Correlation between independent variables and preference of extension approaches

\begin{tabular}{|c|c|c|c|c|}
\hline \multirow{3}{*}{\multicolumn{2}{|c|}{ Independent variables }} & \multicolumn{3}{|c|}{ Correlation Coefficient } \\
\hline & & \multirow{2}{*}{$\begin{array}{l}\text { Individual farmer } \\
\text { interaction }\end{array}$} & \multirow[b]{2}{*}{ Group approach } & \multirow[b]{2}{*}{ Mass media } \\
\hline & & & & \\
\hline \multicolumn{2}{|l|}{ Gender } & -0.041 & $0.123^{*}$ & -0.078 \\
\hline \multicolumn{2}{|l|}{ Age } & 0.105 & -0.042 & 0.102 \\
\hline \multicolumn{2}{|c|}{ Educational level } & $0.154^{* *}$ & -0.007 & 0.006 \\
\hline \multicolumn{2}{|c|}{ Years of farming experience } & 0.086 & -0.066 & 0.094 \\
\hline \multicolumn{2}{|c|}{ No. of non formal trainings } & -0.044 & 0.070 & 0.097 \\
\hline \multicolumn{2}{|c|}{ Occupation of the Household Head } & 0.107 & -0.019 & -0.008 \\
\hline \multicolumn{2}{|c|}{ Reason for farming } & 0.053 & 0.036 & $-0.19 * *$ \\
\hline \multicolumn{2}{|c|}{ Estimated income from the farm } & 0.095 & -0.031 & -0.061 \\
\hline \multicolumn{2}{|c|}{ Wealth status } & 0.108 & -0.117 & $-0.129 *$ \\
\hline \multicolumn{2}{|c|}{ Membership of groups } & -0.002 & 0.096 & -0.048 \\
\hline \multicolumn{2}{|c|}{ Farm size } & -0.058 & $0.124^{*}$ & $0.153 * *$ \\
\hline \multicolumn{2}{|c|}{ Fertility status of Land } & $-0156 * *$ & $0.193 * * *$ & 0.084 \\
\hline \multicolumn{2}{|c|}{ Security of Tenure } & 0.079 & -0.008 & 0.026 \\
\hline \multicolumn{2}{|c|}{ Possession of Radio } & $0.153 * *$ & $0.204 * * *$ & 0.019 \\
\hline \multicolumn{2}{|c|}{ Possession of TV } & 0.076 & -0.046 & -0.013 \\
\hline \multicolumn{5}{|c|}{ Note:*significant at $\mathrm{P} \leq 0.05, \quad * *$ significant at $\mathrm{P} \leq 0.01, * * *$ significant at $\mathrm{P} \leq 0.001$} \\
\hline \multicolumn{2}{|c|}{$\begin{array}{lll}X & \text { Independent } & \text { Variable } \\
\text { variable } & & \end{array}$} & \multicolumn{3}{|c|}{ Values of Variables } \\
\hline & Gender(HH) & \multicolumn{3}{|l|}{ Male $=1$, Female $=2$} \\
\hline & Age $(\mathrm{HH})$ & \multicolumn{3}{|l|}{ Continuous variable } \\
\hline $\mathrm{X}_{3}$ & Education level $(\mathrm{HH})$ & \multicolumn{3}{|c|}{$\begin{array}{l}\text { No education }=1 \text {, Primary Education }=2 \text {, Secondary Education }=3 \text {, Tertiary } \\
\text { Education }=4\end{array}$} \\
\hline $\mathrm{X}_{4}$ & Years of experience & \multicolumn{3}{|c|}{ Less than 10 years $=1,11-20 \mathrm{yrs}=2$, Above 20 years $=3$} \\
\hline $\mathrm{X}_{5}$ & $\begin{array}{l}\text { No. of non formal } \\
\text { trainings }\end{array}$ & \multicolumn{3}{|c|}{ None $=1,1-5$ times $=2,5-10$ times $,=3,>10$ times $=4$} \\
\hline $\mathrm{X}_{6}$ & Occupation $(\mathrm{HH})$ & \multicolumn{3}{|c|}{ Farming $=1$, business $=2$, employed $=3$} \\
\hline $\mathrm{X}_{7}$ & Reason for farming & \multicolumn{3}{|c|}{ For food $=1$, for income $=2$, for food and income $=3$} \\
\hline $\mathrm{X}_{8}$ & $\begin{array}{l}\text { Estimated income from } \\
\text { farming }\end{array}$ & \multicolumn{3}{|c|}{$0-5,000=1,5,00010,000=2,10,000,15,000=3,>15.000=4$} \\
\hline $\mathrm{X}_{9}$ & Wealth status & Rich $=1$, Average $=2$, Poor $=3$ & & \\
\hline $\mathrm{X}_{10}$ & Membership of groups & Continuous variable & & \\
\hline
\end{tabular}




\begin{tabular}{|c|c|c|}
\hline $\begin{array}{l}\mathrm{X} \\
\text { variable }\end{array}$ & Independent Variable & Values of Variables \\
\hline $\mathrm{X}_{11}$ & $\begin{array}{l}\text { Fertility status of the } \\
\text { farm }\end{array}$ & High $=1$, low $=2$, does not know $=3$ \\
\hline $\mathrm{X}_{12}$ & Farm size & Continuous variable \\
\hline $\mathrm{X}_{13}$ & Security of tenure & $\mathrm{Yes}=1, \mathrm{No}=2$ \\
\hline $\mathrm{X}_{14}$ & Possession of Radio & $\mathrm{Yes}=1, \mathrm{No}=2$ \\
\hline $\mathrm{X}_{15}$ & Possession of TV & $\mathrm{Yes}=1, \mathrm{No}=2$ \\
\hline
\end{tabular}

\section{Multiple linear regression results}

Results in Table 9 indicate that education $(\mathrm{t}=2.77, \mathrm{P} \leq 0.01)$, wealth status $(\mathrm{t}=3.76, \mathrm{P}<0.001)$, fertility status ( $\mathrm{t}=-$ $2.30, \mathrm{P}<0.05)$ and security of tenure $(\mathrm{t}=2.70, \mathrm{P}<0.01)$ jointly explain a significant amount of variation to the extend of $17 \%$ in farmers' preference of individual farmer interaction as extension approach in dissemination of soil fertility management practices. Multiple correlation coefficients (R) showed 39\% relationship between farmers' preference for group approach and all independent variables indicated on the table. In preference for mass media, reason for farming and size of the farm explained $19 \%$ and $16 \%$ respectively of the variance. This denotes that reason for farming is a stronger predictor compared to the other variables.

Table 9: Predictors of extension approaches preference by farmers

\begin{tabular}{|c|c|c|c|c|c|c|}
\hline \multirow{2}{*}{ Independent Variable } & \multicolumn{2}{|c|}{ Individual farmer interaction } & \multicolumn{2}{|c|}{ Group approach } & \multicolumn{2}{|c|}{ Mass media } \\
\hline & Beta & $\mathbf{t}$ & Beta & $\mathbf{t}$ & Beta & $\mathbf{t}$ \\
\hline (Constant) & 0.67 & 1.27 & 2.42 & 4.75 & 2.17 & 3.62 \\
\hline Gender (Decision maker) & 0.00 & -0.02 & 0.10 & 1.48 & -0.09 & -1.37 \\
\hline Age of household head & 0.09 & 1.11 & -0.01 & -0.12 & -0.03 & -0.36 \\
\hline Educational level of Household Head & 0.21 & $2.77 * *$ & -0.01 & -0.13 & -0.07 & -0.89 \\
\hline Years of farming experience & 0.06 & 0.75 & -0.11 & -1.30 & 0.10 & 1.17 \\
\hline Non formal trainings & -0.12 & -1.79 & 0.15 & $2.12 *$ & 0.13 & 1.77 \\
\hline Occupation of Household head & 0.06 & 0.84 & -0.04 & -0.49 & -0.01 & -0.10 \\
\hline Reason for farming & 0.03 & 0.40 & 0.10 & 1.52 & -0.19 & $-2.66^{* *}$ \\
\hline Estimated income earned from farming & 0.09 & 1.25 & -0.01 & -0.14 & 0.01 & 0.14 \\
\hline Wealth status & 0.26 & $3.67 * * *$ & -0.07 & -0.99 & -0.10 & -1.36 \\
\hline Membership of groups & 0.06 & 0.80 & -0.04 & -0.54 & -0.11 & -1.51 \\
\hline Farm size(acres) & 0.02 & 0.27 & 0.12 & 1.76 & 0.16 & $2.26^{*}$ \\
\hline Fertility status of your farm & -0.15 & $-2.30 *$ & 0.20 & $3.07 * *$ & -0.09 & -1.28 \\
\hline Security of tenure & 0.19 & $2.70 * *$ & 0.02 & 0.24 & 0.06 & 0.90 \\
\hline Possession of Radio & 0.12 & 1.80 & -0.21 & $-3.21 * *$ & 0.08 & 1.18 \\
\hline Possession of TV & -0.08 & -1.06 & -0.06 & -0.87 & -0.02 & -0.21 \\
\hline $\mathrm{R}$ & 0.41 & & 0.39 & & 0.34 & \\
\hline $\mathrm{R}$ square & 0.17 & & 0.15 & & 0.12 & \\
\hline $\mathrm{F}$ & $3.05 * * *$ & & $2.70 * * *$ & & $1.97 *$ & \\
\hline
\end{tabular}

\section{DISCUSSIONS}

Based on the research finding farmers obtain information from government extension agents, researchers, NGOs, other farmers, radio, agro input dealers, friends, and exhibition and also utilize their own knowledge. The results reveal that farmers perceived other farmers as the most available source of information with a mean score of 3.8 . This agrees with the findings of Oladoja (2008) that the farmer plays a vital role in the process of change; he is not only a receiver of agricultural information but also a source as well as a channel relaying the information to get others. Radio was considered the second most available source of information with a computed mean of 3.6. The implication of this study finding was that because most respondents posses a radio, it was then a readily available source of information. In addition, the radio as a mass communication method reaches many farmers within a short time compared to other knowledge sharing tools. Other farmers were also perceived as the most reliable source of information as it was ranked first (1) with a computed mean of 3.09. This agrees with the findings of Maddox et al. (2003) found other farmers to be a major source of information. Radio/TV were ranked $2^{\text {nd }}$ on availability but $4^{\text {th }}$ on its reliability. This suggests more reliable information related to soil fertility should be broadcasted through the radio to make use of its availability. The farmers also indicated that researchers were not very accessible as they were ranked $5^{\text {th }}$ but are more reliable $\left(3^{\text {rd }}\right)$. Thus, researchers should improve their interaction with the farmers for better delivery of soil fertility messages. According to the result findings, there was a positive correlation $(\mathrm{r}=0.65)$ between availability of information source and its reliability. The implication of the results is that availability of information positively influences its reliability by the farmers. This suggests information sources should be readily available for farmers to make utmost use of them. Rezvanfar et al., (2009) reported that access to information sources and communication channels and adequate number of extension education courses with relevant content may increase awareness about the effects and consequences of 
sustainable soil conservation practices among farmers while providing them with required knowledge.

Different extension methods had been used to teach farmers on different SFM practices. Demonstration was perceived as the most preferred method in dissemination of SFM practices as it was ranked first followed by farmer to farmer extension, workshops, field days, FFS, use of teaching aids and exchange visits respectively. Other studies asking specifically about farmers' information sources for environmental issues found on farm demonstration as the most preferred communication channel (Bruening, 1991). Individual farmer interaction approach was strongly preferred by majority of the farmers. This implied that farmers would like to be visited in their own individual farms .According to Farouque and Takeya (2009) individual teaching methods are superior for instilling conviction and motivating action. The individual method enhances interaction which may enhance much emphasis on the technology thereby enhancing better understanding (Okunade, 2007). Therefore, farmers' preference for individual teaching method to adopt SFM practices was rational. However, it has been reported that individual farmer approaches have been slow and have not resulted in better farm management (Thomas et al., 1997).

In this study, wealth status and education were found to be significant predictors of preference for individual farmer interaction approach but non significant in prediction of preference of group and mass media approaches. This implied that more educated and wealthy farmers have a great preference for individual farmer interaction approach. This agrees with the findings of Bukenya et al. (2008) that well off farmers are often more reluctant to learn with other farmers or groups. Mendis and Udomsade (2005) found there was significant relationship between level of education and adoption of soil improvement practices, thus education will also determine the extension method used for the different SFM practices. Gender was not found to be a predictor of preference of group approach, however it was found to be significantly correlated with preference of group approach. Farmers who do not posses radio are not likely to prefer group approach as an extension method. Lack of radio may be associated with poverty, thus farmers would more likely suffer from inferiority and would not be willing to be associated with others. This study has also established that farm size and reason for farming are significant predictors in farmers' preference for mass media as an approach in teaching of SFM practices. Farmers with large parcels of land are perceived to seek information from other sources like mass media to improve soil fertility of their land. These findings are similar to the findings reported by Farouque and Takeya (2009) that farmers with large portions of land had a high preference for mass teaching methods.

\section{CONCLUSION}

Based on the research findings, farmers obtain information on soil fertility management from different sources. However, for the farmers to make good decisions they need help to integrate the information. It is therefore important to put the government extension agent in the centre or at least make him part of every soil fertility related campaigns. Farmers were ranked as one of the most available and reliable source of SFM information. Demonstration was considered as the most preferred extension teaching method in dissemination of soil fertility management practices. However, FFS was ranked the highest in teaching on compost while farmer to farmer extension method was ranked as the most preferred in teaching of soil control measures, green manure and crop rotation. In view of the above findings it is hence recommended that a combination of different extension methods with farmers' involvement be used in teaching of soil fertility management practices. It is also clear from the above findings that different categories of farmers require different extension approaches. According to the multiple regression analysis, education, wealth status, security of tenure and fertility status of land are important factors to consider in selection of individual interaction methods while number of non formal trainings attended, fertility status of land, and possession of radio are significant when considering group methods. When agents use methods compatible with their clientele they will be both more effective and efficient. It is therefore pertinent that researchers and extension agents consider farmers, social-economic characteristics in selection of extension teaching methods in dissemination of soil fertility management research findings.

\section{REFERENCES}

Adebayo, K. (1997). Communication in Agriculture, Integrity Prints, Nigeria, pp 1-60

Ashby, J. (2003). Uniting Science and Participation in the process of innovation. Resource for Development. In Managing Natural Resources for Sustainable Livelihoods. Uniting Science and Participation. (Eds Pound, B., Snapp, S., McDougall, C and.Braun.A) Earth scan Publications Ltd, London IDRC, Canada), pp 1-25.

Bruening, T. H. (1991). Communicating with farmers about environmental issues. Journal of applied communicators, 75 (1) pp 34-41

Bukenya, M. Bbale, W. and Buyinza, M. (2008). Assessement of the Effectiveness of individual and Group extension methods: A case study of Vi-Agro forestry Project in Uganda Research Journals of Applied Sciences 3 (3) pp 250-256

Ekoja, I. (2003). Farmer's Access to agricultural information in Nigeria. Bulletin of the American Society For Information Science And Technology, August/Sep., pp: 21- 23. Evaluation. Washington, DC: The World 
Bank

Farouque, M. G. and Takeya, H. (2009). Adoption of Integrated Soil fertility and Nutrient Management Approach: Famers', Preferences for Extension Teaching Methods in Bangladesh Nagoya-Shi, Japan International Journal of Agricultural Research 4 (1) pp 29-37,

Garforth, C. (1998). Dissemination pathways for renewable natural resources [RNR] research. Socio-economic Methodologies for Natural Resources Research. Best Practice Guidelines (BPG 1). Natural Resources Institute (NRI), Chatham, UK

Jaetzold, R., Schmidt, H. Hornet, Z. B. and Shisanya, C. A. (2006). Farm Management Handbook of Kenya. Natural Conditions and Farm Information. 2nd Edition. Vol.11/ C. Eastern Province. Ministry of Agriculture/GTZ, Nairobi, Kenya

Kamau, G. M., Karanja, G.M. Ndubi, J. M and Kimani I. W. (2000). ATIRI Booklet (Revised) Kenya Agricultural Research Institute. Nairobi, Kenya

Maddox, S. J., Mustian, D. and Jenkins, D. M. (2003). “Agricultural Information Preferences of North Carolina Farmers." A Paper Presented to the Southern Association of Agricultural Scientists, Agricultural Communications Section, Mobile, Alabama

Mendis, U. I and Udomsade. J. (2005). Factors affecting Adoption of Recommended Crop Management practices in Paddy Cultivation in Kalutara District, Sri Lanka Kasetsart journal of Social Sciences 26 pp 91102

Mugwe, J. Mugendi, D. Mucheru-Muna, M. Merckx, R. Chianu, J. and Vanlauwe, B (2009). Determinants of the decision to adopt Integrated soil fertility management Practices by smallholder farmers in the Central highlands of Kenya Experimental Agriculture 45, pp 47-59

Okunade, E. O. (2007). Effectiveness of extension teaching methods in acquiring knowledge, skill and attitude by women farmers in Osun state. Journal of applied Sciences Research., 3; pp 282-286

Oladoja, M. A., Adeokun. O.A. and Fapojuwo, O.E. (2008). Determining the Social Economic Factors Affecting Farmer's Use of Communication Methods for Information Sourcing in Oluyole Local Government Area of Oyo State, Nigeria Pakistan Journal of Social Sciences 5 (1) pp 51-56

Onduru, D. D., Muchena, F. M..Gachimbi, L and Maina, F. (2002). Integrated Nutrient Management to attain sustainable productivity increases in East African farming Systems (INMASP) East Africa Experiences with Farmer field Schools in Kenya INMASP Report No, $0125^{\text {th }}$ January 2002. (INMASP Project ETC East Africa /KARI (NARL)

Rezvanfar, A., Samiee. A. and Faham .E. (2009). Analysis of Factors Affecting Adoption of Sustainable Soil Conservation Practices among Wheat Growers World Applied Sciences Journal 6 (5) 2009ISSN 1818-4952 (C) IDOSI Publications pp 644-651,

Richardson, J. G. and Mustian, R. D (1994). Delivery Methods preferred by the target clientele for receiving specific Information. Journal Applied communication 8: pp 22-31

Riesenberg, L E. and Gor C.O (1989) "Farmers' Preferences for Methods of Receiving Information on New or Innovative Farming Practices.” Journal of Agricultural Education, Vol. 30, No. 3, Fall, pp. 7-13.

Rogers. E. M. (1995). Diffusion of innovation $4^{\text {th }}$ Edition. The free press, New York, ISBN: 266718

Sanchez, P. A., Shepherd, K. D. Soule, M. J. Place, F. M.,Buresh, R. J. Izac, A. M. N. Mokunyeje, A. U. Kwesiga, F. R. Ndiritu, C. G and Woomer,P. L. (1997). Soil fertility replenishment in east Africa: An Investment in natural resource capital in Buresh et al 1997 Replenishing soil fertility in Africa. SSSA special publication 51 SSSA, Madson, W1. pp 1-46.

Sim, D. and Hilmi. H. A. (1987). Forestry extension methods. FAO Forestry Paper 80. FAO, Rome Italy

Thomas, D. B., Eriksson, A. Grunder, M. and Mburu, J.K. (Eds.) (1997). Soil and water conservation manual for Kenya. Soil and Water Conservation Branch, Ministry of Agriculture, Livestock Development and Marketing, Republic of Kenya. Nairobi. 